\title{
SYNOPSIS
}

News

$\bullet$

AnALYSIS

- Practice

Medical Device Recall

\section{Physicians want transparency as Guidant lawsuits grow}

Canadian physicians who implant cardiac defibrillators are calling on Guidant Corporation and other manufacturers to notify doctors and patients as soon as device failures occur.

"All of this information has to be provided to the stakeholders in a timely way, and there has to be complete openness and transparency," says Dr. Chris Simpson, president of the Canadian Heart Rhythm Society and director of the arrhythmia service at Kingston General Hospital.

In Canada, 962 people were affected this spring and summer by Guidant Canada's recall of several models of implantable cardiac defibrillators (ICDs), which was triggered by a frontpage New York Times story saying the company had concealed problems with one model for 3 years. (For a chronology see www.cmaj.ca/cgi/content/full/173 /8/855/DC1)

Guidant also recalled several pacemaker models because seals were prone to gradual deterioration, potentially depleting the device's batteries; 1622 Canadians were affected by that recall.

The Times began to investigate the ICDs when 21-year-old Joshua Oukrop died of cardiac arrhythmia in March after the Guidant Ventak Prizm 2 DR 1861 he had implanted in 2001 failed to shock his heart back into rhythm. A subsequent analysis of the device revealed that it had short-circuited - a problem Guidant told Oukrop's doctors that it knew about but was not planning to tell doctors and patients. The physicians then went to the Times.

Although Guidant detected the problem in 2002 and fixed subsequent models, it continued to sell those manufactured before 2002 and did not inform physicians or patients about the potential for device failure.

The first time most US cardiologists and cardiac electrophysiologists learned of the problem was May 23 - just hours before the Times hit the streets with its front-page story. A securities lawsuit filed in Indiana against Guidant Corporation alleges that Guidant executives, including the company's chief medical officer, who sold $\$ 1.7$ million in stock options the day before the Times story appeared, engaged in insider trading.

Guidant Corporation first contacted Health Canada about the ICDs on May 24, according to the company. Guidant subsequently recalled the devices in the US and issued several Dear Doctor letters, amounting to a recall in Canada.

Guidant's rationale for not notifying physicians or patients sooner was that the device's potential to short circuit did not significantly increase the failure rate. A published transcript of an interview with Fred McCoy, president of Guidant's cardiac rhythm management division, quotes McCoy as saying the company's defibrillators and pacemakers "aspire to a $99 \%$ reliability level."

Guidant acknowledges at least 2 deaths connected with problems in 2 different ICD models. Generally, Guidant cites a failure rate of less than $1 \%$ for

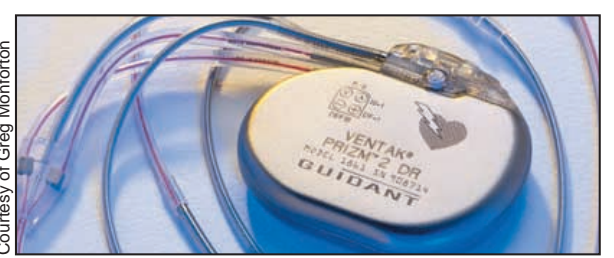

This implantable cardiac defibrillator is central to a Canadian class-action lawsuit.

all recalled ICDs and pacemakers. The company acknowledges, however, that failure rates may be higher because of underreporting and lack of postmortem evaluations.

On Aug. 22, lawyers James Newland, Brian Moher and Greg Monforton filed a class-action lawsuit in the Ontario Superior Court of Justice against Guidant Corporation, Guidant Canada, and subsidiaries. The lawsuit demands $\$ 510$ million on behalf of lead claimant Herbert Heron and an estimated 2500 other Canadians. The lawsuit alleges that Guidant breached its duty of care toward the claimants and "engaged in conduct which favoured their commercial interests over patient safety." The statement of claim also contends the corporation "failed to interpret or report data from pre-market testing in an accurate and objective manner to the [US Food and Drug Administration (FDA)] and Health Canada."

Heron, who required his defibrillator because of his history of severe cardiac arrhythmia, had his device removed Aug. 16 after learning of the recall. In the lawsuit, he says he has "lost confidence that the defendants will in the future act as a responsible de- 
vice manufacturer should."

"These are people who have a life-threatening condition to begin with, so on top of that, you're layering not only the risks and trauma, both physical and psychologically associated with future surgery, but also the dread," Monforton said of his clients.

In Kingston, Simpson said most of his 100 or so potentially affected patients weren't initially concerned that they are at "a horrible risk." But after Simpson advised them of the potential consequence of device failure and risk of infection (about 2\%) from replacement surgery, about 15 chose surgery.

"What most patients are upset about is the fact that the process was flawed," he says. "Physicians and patients weren't notified in a timely way."

At a Sept. 16 conference in Washington, DC, the Canadian and US Heart Rhythm societies joined representatives from the FDA, manufacturers and patients to develop a new process to notify doctors, patients and regulators about medical device failures. The group is striking a task force to draft recommendations. (As noted in a New England Fournal of Medicine article [353:3; 221-224], the US Heart Rhythm Society receives $25 \%$ of its annual budget from Guidant, Medtronic, and St. Jude Medical, as well as other medical device corporations. The Canadian society has no corporate sponsors.)

Existing FDA regulations require companies to file annual reports that register any significant manufacturing changes to devices - something Guidant says it did in 2002 after it first detected and fixed the short-circuiting problem in its ICDs. The FDA will not release those annual reports, calling them "corporate trade secrets."

"The health and safety of patients is our highest priority," says Marie Weller, a spokesperson for Guidant Corporation. "Our innovative technologies have saved and improved millions of lives." Guidant is committed to the public discussions about when "very low frequency device dysfunction trends should be communicated."

Although Guidant may have followed the existing rules, says Simpson, there are no regulations that require the manufacturers to notify doctors and patients about adverse medical device events.

"The response of doctors and patients to that is that's a very paternalistic approach," Simpson says. "We make the medical decisions; you don't make the medical decisions." - Laura Eggertson, CMAJ

\section{Editorial Fellow}

\section{Looking at the big picture}

Sally Murray brings a passion for public health and a love of writing to her new role as the 8th Editorial Fellow at CMA7. Murray, an Australian physician, has worked in international health in

Kenya, Ethiopia, Eritrea and at

毒 the WHO in Geneva. She also

has experience as a freelance writer

After graduating from medical school in 1996, Murray spent time in emergency medicine, but was unsatisfied with clinical med-

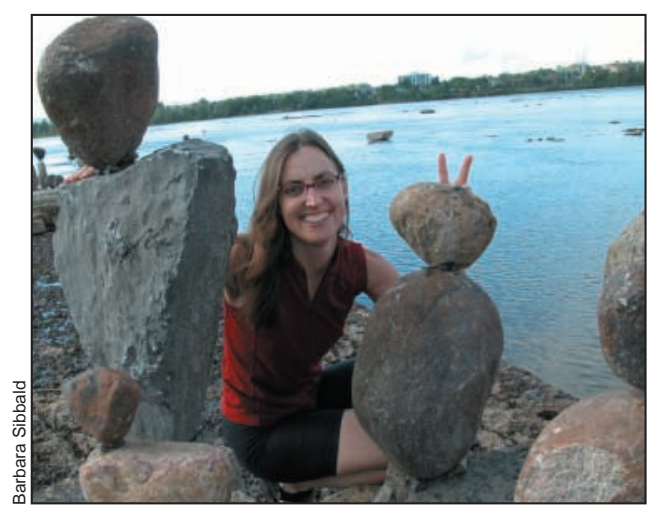

Murray enjoying the Ottawa outdoors. (Rock sculptures on the Ottawa River by JohnFélice Ceprano.) icine. "It doesn't explain why people get sick," she describes. "I'm attracted to 'big picture' health, how to address things that affect the health of 2000 people rather than one. I'm fascinated with how things fit together and influence each other."

Her interest in the 'big picture' first led Murray to sociology and women's studies before she completed her master's degree in Public Health and Tropical Medicine and a second master's in Public Health Practice. In 2003, Murray was awarded the Australasian Faculty of Public Health Medicine Medal for best graduating fellow; she also topped her class in both master's degrees.

In 2004 Murray and her husband, Dr. Hakan Yaman, worked in Kenya with MSF on an antiretroviral therapy program. "Being a twin got me interested in equity," quips Murray. She adds, "There are plenty of equity problems there. It still makes me angry. People die every day from treatable disease for no reason other than being poor. Our program treated only 2000 of the 40000 in the area who needed antiretrovirals. How would you feel if your mother or brother missed out?"

Murray's move to CMA7 reflects her interest in "reaching the masses" and the power of the printed word. She is particularly drawn to medical journalism, in part because "it's not always done well," she says, "and what we write or print influences how people act. It's important to be less sensational and more accurate," Murray reflects. "We've got to get that right."

CMA7's fellow, who acts as an associate scientific editor, spends a year reviewing submissions, corresponding with authors and working closely with the senior editorial team to develop clinical and editorial content.

Applications for the 2006 editorial fellowship must be received by Dec. 15, 2005 (www .cmaj.ca/misc/fellowship.shtml). - Barbara Sibbald, CMAJ 